molto diffuso. L'infezione primaria, generalmente nella prima infanzia, è, di solito, asintomatica. Il virus persiste tuttavia nell'ospite in forma latente, a livello renale, ma anche nei linfociti e nel cervello. BKV può poi andare incontro a riattivazioni che sono contraddistinte da eliminazione del virus nelle urine. Anche gli episodi di riattivazione sono generalmente asintomatici, tranne che in pazienti fortemente immunodepressi quali soprattutto quelli sottoposti a trapianto sia di midollo che di organi solidi. In questi gruppi di pazienti le riattivazioni di BKV sono estremamente frequenti e possono essere associate a cistite emorragica, nei trapiantati di midollo osseo, e a nefrite interstiziale, soprattutto nei trapiantati renali. La diagnosi di laboratorio di cistite emorragica-BKV associata così come quella di nefropatia-BKV associata si basa anche sulla ricerca del poliomavirus nelle urine, tramite l'impiego di saggi di amplificazione del DNA virale. Data la frequenza di riattivazione asintomatiche, accompagnate da viruria, sia pure di lieve entità, solo test quantitativi possono consentire di distinguere la riattivazione asintomatica dalla riattivazione più intensa associata alle manifestazioni patologiche. Oltre alla ricerca del virus nelle urine è emersa recentemente anche l'importanza, ai fini diagnostici, della ricerca del virus nel sangue periferico e, nella nefropatia-BKV associata, anche nel tessuto renale. Sono in corso di valutazione protocolli per il monitoraggio dell'infezione da BKV nei trapiantati renali che possano portare all'individuazione di pazienti a rischio di nefropatia da BKV.

\title{
S9.3
}

\section{LE DETERMINAZIONI QUANTITATIVE NEL PAZIENTE CON INFEZIONE DA poliomavirus BK}

\section{Azzi A.}

Dipartimento di Sanità Pubblica, Università di Firenze

Il poliomavirus umano BK (BKV) è ubiquitario e 